\title{
Balkanologie
}

Balkanologie Revue d'études pluridisciplinaires

Vol. VIII, $n^{\circ} 2$ | 2004

Volume VIII Numéro 2

\section{Change the regime - change the money: Bulgarian banknotes, 1885-2003}

Changer de régime - changer d'argent : les billets de banque bulgares, 1885-2003

Adrian E. Tschoegl

\section{OpenEdition}

12 Journals

Electronic version

URL: http://journals.openedition.org/balkanologie/533

DOI: 10.4000/balkanologie.533

ISSN: 1965-0582

\section{Publisher}

Association française d'études sur les Balkans (Afebalk)

\section{Printed version}

Date of publication: 1 December 2004

ISSN: 1279-7952

\section{Electronic reference}

Adrian E. Tschoegl, «Change the regime - change the money: Bulgarian banknotes, 1885-2003 », Balkanologie [Online], Vol. VIII, n² 2 | 2004, Online since 20 January 2010, connection on 17 December 2020. URL : http://journals.openedition.org/balkanologie/533 ; DOI : https://doi.org/10.4000/ balkanologie.533 


\title{
CHANGE THE REGIME - CHANGE THE MONEY: BULGARIAN BANKNOTES, 1885-2003
}

\author{
Adrian E. Tschoeg/*
}

This paper follows the changes in the images in Bulgaria's notes from the first issue in 1885 to the most recent in 2003. In that period, Bulgaria has gone from being a monarchy to a Communist Peoples' Republic then to a Parliamentary Republic, and the pictorial elements of its money have reflected those changes. Although it is an obvious point that changes in political regimes lead to changes in the images on the emanations of the State, be they its banknotes, coins, flags, or postage stamps, still this point has not appeared in the literature on these emanations ${ }^{1}$.

\section{BANKNOTES AND THE IDEA OF NATIONAL MONEY}

We see money every day, but because of its familiarity we rarely observe it. Though often aesthetically beautiful, a banknote is an oblong piece of paper without intrinsic value ${ }^{2}$. However, the banknote is also a means of communication ; it has symbols and images on it that carry information. Banknotes represent a unique documentation because they combine in one medium com-

\footnotetext{
- Adjunct Associate Professor of Management, The Wharton School of the University of Pennsylvania, Philadelphia, tschoegl@alum.mit.edu

${ }^{1}$ I would like to thank Stanley Brunn, John Dunn, Jeffrey Miller and Georgi Spiridonov who assisted in diverse ways and Anca Metiu who provided helpful comments on an earlier draft. I would like to thank as well Garry Saint Esq. of Numismondo who kindly made available excellent scans of the banknotes that I have used in this paper.

${ }^{2}$ For a beautifully illustrated tour d'horizon see : Standish (David), The Art of Money : The History and Design of Paper Currency from around the World, San Francisco : Chronicle Press, 2000.
} 
peting and colluding discourses: financial, aesthetic, and political ${ }^{3}$. Some of the design elements describe the banknote's history and identity : the decree authorizing its production, the name of the issuing institution, the names of the artists involved, identifiers of the series to which it belongs, and its serial number 4 . Those elements that convey the identity and denomination are essential to its financial function as a store of value. Other design elements such as intricate geometrical figures, Guilloche elements and the like, are primarily devices to impede counterfeiting, though they may reflect the aesthetic fashions of the times 5 . They have a derived importance to the function of money in that they support the trust on which money, which is socially constructed, relies. Lastly, money often carries on it images of people, places or things. The intricacy of these pictures too serves to impede counterfeiting and the issuers of money could and occasionally do pick them arbitrarily, looking simply for attractive images. But the images are rarely arbitrary ; instead, they are often symbolic and didactic.

We can define iconography as the traditional or conventional images or symbols associated with a subject. Flags clearly can be icons in themselves and often depict icons ${ }^{6}$. Similarly, currency may be an icon (the US "greenback ") and depict icons 7 . One of the functions of national currency is to cultivate nationality, that is, to create a sense of collective identity that binds the inhabitants of a territory together ${ }^{8}$. The early studies of the iconography of banknotes dealt with the depiction of women, Native Americans and African Americans, and the designs of Eliel Saarinen 9 . More recently, researchers have started to examine the political meaning of the imagery on banknotes. The cases they analyze include British colonies, Canada, Kenya, the United

${ }^{3}$ Kim (E.), “ Race Sells : Racialized Trade Cards in $18^{\text {th }}$ Century Britain ", Journal of Material Culture, 7 (2), 2002.

4 Mugnaini (Fabio), « Messages sur billets de banque : la monnaie comme mode d'échange et de communication ", Terrain, (23), 1994. Mugnaini's paper focuses on the graffiti that often adorn circulating notes in Italy.

5 Bolten (Jaap), Dutch Banknote Design 1814-2002 : A Compendium, Amsterdam : De Nederlandsche Bank, 1999.

${ }^{6}$ Matjunin (Serguei), "The new state flags as the iconographic symbols of the post-Soviet space ", GeoJournal, 52 (4), 2001, pp. 311-313.

7 Helleiner (Eric), " Historicizing territorial currencies : monetary space and the nation-state in North America ", Political Geography, 18 (3), 1999.

8 Ibid.

9 Hewitt (Virginia), Beauty and the Banknote : Images of Women on Paper Money, London : British Museum, 1994. Natmeßnig (C.), "An den Frauen haben wir ohnhin einiges gutzumachen... ", in Bachinger (Karl), Stiefel (Dieter), eds., Auf Heller und Cent : Beiträge zur Finanz- und Währungsgeschichte, Wien : Wirschaftsverlag Ueberreuter, 2001. Doty (Richard D.), " Surviving images, forgotten people : Native Americans, women, and African Americans on United States obsolete banknotes ", in Hewitt (Virginia), ed., The Banker's Art : Studies in Paper Money, London : British Museum, 1995. Talvio (Tuuka), "Something characteristic of our land : Eliel Saarinen as a banknote designer n, in Hewitt (Virginia), ed., op.cit. 
Kingdom, and Uzbekistan ${ }^{10}$. The present paper builds on that literature by looking at how the imagery changes in response to political changes. When political regimes change, the images on a country's money change too. Sometimes the new notes are triumphant. The 19835000 rial and 19862000 rial Iranian notes feature crowds of supporters of Ayatollah Khomeini surging forward with banners, some bearing his portrait. More generally, the new regime typically wishes to create different traditions, to teach different lessons and to introduce different symbols. At the same time it seeks to establish its legitimacy by establishing a link to a heroic or idealized past or, in the cast of Communist Regimes, to an idealized present. Thus the study of the iconography of banknotes, and similar state emissions, can contribute to the understanding of the emergence of national identity ${ }^{11}$. B. Cohen argues that from the Treaty of Westphalia (1648) on, we have seen the diffusion of the idea of the sovereign state with its emotionally laden symbols of identity : one army, one flag and one currency ${ }^{12}$. However, as E. Helleiner points out, national money coterminous with the national territory is really a creation of the $19^{\text {th }}$ Century and later ${ }^{13}$. The creation of national money began first in the United Kingdom and Continental Europe, and then radiated out. In some parts of the world national money arrived late. The Maria Theresa Thaler (or Dollar), with a design unchanged since 1780 , circulated as the medium of exchange in parts of Africa and the Middle East until the second half of the $20^{\text {th }}$ Century. In the Balkans it was legal tender in the Ionian Islands from 1836 to 1877 and it circulated in Greece until $1882^{14}$. In other parts of the world, national money never arrived. Panama has used the US dollar as its money since 1904. Lastly, since January 1, 2002, twelve nations in Europe - pioneers in the development of national money - adopted a common currency, the euro.

\footnotetext{
${ }^{10}$ Hewitt (Virginia), " A distant view : imagery and imagination in the paper currency of the British Empire, 1800-1960 ", in Gilbert (Emily), Helleiner (Eric), eds., Nation-States and Money, New York : Routledge, 1999 ; Gilbert (Emily), "Forging a national currency : money, state-building and nation-making in Canada n, in Gilbert (Emily), Helleiner (Eric), eds., op.cit. Blaazer (David), "Sterling Identities ", History Today, (1), 2002. Mwangi (Wambui), "The Lion, the Native and the Coffee Plant : Political Imagery and the Ambiguous Art of Currency Design in Colonial Kenya n, Geopolitics, 7 (1), 2002. Gillbert (Emily), "Ornamenting the façade of hell: iconographies of $19^{\text {th }}$-Century Canadian paper money ", Society and Space, 16 (1), 1998. Dunn (John), " The Paper Nation : Nationalist Iconography as Reflected on Uzbek Banknotes ", Journal of Central Asian Studies, (2), 1999.
}

${ }^{11}$ Connor (Walker), "When is a nation ? ", Ethnic and Racial Studies, 13 (1), 1990.

${ }^{12}$ Cohen (Benjamin J.), The Geography of Money, Ithaca : Cornell University Press, 1998.

${ }^{13}$ Helleiner (Eric), The Making of National Money : Territorial Currencies in Historical Perspective, Ithaca : Cornell Univ. Press, 2003.

14 Tschoegl (Adrian E.), " Maria Theresa's Thaler : A Case of International Money ", Eastern Economic Journal, (4), 2001. 
Still, currency can provide a vehicle for nationalist imagery that constructs a sense of collective tradition and memory ${ }^{15}$. As the ideology of nationalism spread, national leaders saw in money a powerful way to disseminate general national symbols or even to make specific irredentist points ${ }^{16}$. Just as currency is more than a simple means of payment, stamps are more than a simple means for postal and financial transactions : " [They are] bearers of some visualized expression of national identity and memory. In other words, the imagery on them visualizes national identity and memory like other lieux de mémoire such as national monuments or architecture. They can thus rightly be called "Portraits of the Nation" ${ }^{17}$.

Visual manifestations of national identity have a further key advantage: the individual viewer can comprehend them, regardless of language, whether domestic or foreign ${ }^{18}$. The imagery promotes the discourses of a dominant ideology and recalls historical triumphs and myths ${ }^{19}$. Sometimes governments, such as those in Communist countries but also those of the European Union (EU), have sought to disseminate symbols that transcend a particular state. In doing so, the governments have necessarily reduced the space they have given to national symbols on banknotes because of the need to allocate space to symbols common to the larger entity. In the case of Communist regimes, the symbols have been ones that emphasize a "Socialist " identity, and this occurred in Bulgaria too (see below). Of all the studies of stamps, banknotes, and the like, W. Mwangi's study of the designs of the banknotes of Kenya is the closest in spirit to the present paper because it is longitudinal and covers at least some important changes in regime. She provides a detailed history of the process of the co-evolution of the iconography of banknotes and national identity for Kenya ${ }^{20}$. From the 1920 s to the early 1960 s, the designs evolved from insisting on white dominance to an ambiguous suggestion of multi-racialism to a doomed attempt at federalism and finally, to African independence. Of course, a key difference between the Kenyan and Bulgarian cases is that throughout the sequence of regime changes in Bulgaria the elites were always indigenous.

${ }_{15}^{15}$ Helleiner (Eric), " National Currencies and National Identities ", American Behavioral Scientist, (10), 1998.

${ }^{16}$ Macedonia designed banknotes with pictures of buildings in Thessalonica on them. Pettifer (James), "The New Macedonian Question (in Macedonia) ", International Affairs, (3), 1992.

${ }^{17}$ Schwarzenbach (Alexis), Portraits of the nation : stamps, coins, and banknotes in Belgium and Switzerland, 1880-1945, New York : Peter Lang, 1999, p. 28.

${ }^{18}$ Ibid.

${ }^{19}$ Cusack (Igor), « Nationalism and the colonial imprint : Stamps of Portugal and Lusophone Africa and Asia ", 2003 (Univ. of Bristol, unpublished paper).

${ }^{20}$ Mwangi (Wambui), art.cit. 


\section{BULGARIA AS PRINCIPALITY AND MONARCHY}

For some five centuries prior to 1878 , Bulgaria was under the rule of the Ottoman Empire. From 1863 the issuer of banknotes for the Empire was an Anglo-French firm, the Imperial Ottoman Bank ${ }^{21}$. Then the 1877-1878 RussoTurkish War resulted in the expulsion of the Ottoman army from what is now Bulgaria. In 1879, an assembly of notables gathered in Turnovo, the medieval capital, to resurrect a Bulgarian state with Alexander Battenberg as its first prince $^{22}$. One of the new government's first moves was to establish the Bulgarian National Bank (Bulgarska Narodna Banka - BNB) in 1879 under its ownership ${ }^{23}$. The BNB then served as the central bank, as the government's fiscal agent and creditor, and as a commercial bank ${ }^{24}$. In 1880, Bulgaria passed the Law on the Bulgarian Lev, which provided for a national currency. With this law, Bulgaria formally adopted the standards of the Latin Monetary Union $(\mathrm{LMU})^{25}$. The basic monetary unit would be the lev (meaning lion ; plural leva) of 100 stotinki (a hundredth ; singular stotinka) ; though the purchasing power of its money has fluctuated, Bulgaria has kept these names ever since. In 1881, the BNB issued its first coins. Next, the 1885 Law on the Bulgarian National

${ }^{21}$ In 1863, British, French and Turkish investors established the Imperial Ottoman Bank (Banque Impériale Ottomane - BIO) on the foundation of an earlier British bank. This bank issued banknotes at its head office in Constantinople (1863-1878) and its branch in Smyrna (1864-1874). Clay (Christopher), " The Bank Notes of the Imperial Ottoman Bank, 1863-1876 ", New Perspectives on Turkey, (9), 1993.

${ }^{22}$ Alexander, Count von Hartenau, né Prince of Battenberg (1857-1893), was elected Prince of Bulgaria in 1879 ; in 1886 army officers forced his abdication. He was a son of Prince Alexander of Hesse and the Rhine (1823-1888) by his morganatic marriage. The English branch of the Battenberg family changed their name to Mountbatten in 1917. Louis Lord Mountbatten of Burma (1900-1979) was a nephew of Prince Alexander of Bulgaria.

23 The Bank translates " narodna " as " national " but the word carries the connotation of Nation or People as in the "Bank of the Bulgarian Nation " or "Bank of the Bulgarian People ". The history of the BNB is from : Avramov (Roumen), ed., 120 Years Bulgarian National Bank, Sophia : Bulgarian National Bank, 1999.

24 Avramov (Roumen), " The Rebirth of the Market in Bulgaria - "Economic Memory" and Transition ", Banki, Investicii, Pari, (5), 1995. This is parallel to the situation in Latin America, especially in Argentina, Brazil, Chile and Mexico where government-owned banks with mixed central, development and commercial banking functions have dominated from the $19^{\text {th }}$ Century. Marichal (Carlos), " Nation building and the origins of banking in Latin America, 1850-1930 ", in Teichova (Alice), Kurgan-van Hentenryk (Ginette), Ziegler (Dieter), eds., Banking, Trade and Industry: Europe, America and Asia from the thirteenth to the twentieth century, Cambridge : Cambridge University Press, 1997.

25 In 1865, France, Italy, Belgium, and Switzerland formed the Union on the basis of earlier de facto agreements to stabilize exchange rates between them. Greece subsequently adhered to the terms of the LMU in 1868, though it did not join formally until 1876. While not members, Spain (1868), Rumania (1868), Bulgaria (1880), Serbia, Venezuela (1891), as well as Austria, Montenegro, S. Marino and the Papal States conformed to the policies of the Union. The Union specified the precious metal content of coins, and their denominations, but was silent on issues of design. The Union disbanded in 1927, some years after it had ceased to have any practical significance. 
Bank granted the Bank the monopoly on banknote issue and made its banknotes legal tender. The BNB issued its first banknotes later that year and when doing so followed the LMU system of denominations of $1,2,5,10,20,50$, and so on ${ }^{26}$.

The first banknotes, the 20 and 50 leva, had only the new Bulgarian coat of arms as a pictorial element. The key element of this coat of arms was a lion rampant dexter (standing on its hind legs, facing to its right and the viewer's left $)^{27}$. A coat of arms of varying design (though retaining the lion) would remain a pictorial element on almost every banknote until $1991^{28}$. In the banknotes of the post-Communist era it survives as a watermark-less immediately visible, but still there. The first use of a picture arrived with the 100 leva note of 1887 . This carried, on its obverse, a picture of a young mother, in national costume, with her arm around a child, and with a sheaf of wheat, a sickle and other implements at her feet. The 18905 leva had on its reverse a ploughman in national costume with a plough and two horses in the foreground, and trees and a house in the background. The 10 leva had on its obverse a woman carrying two panniers of roses - a detail from the engraving Rose-picking near Kazanluk by Felix Kanitz ${ }^{29}$. The reverse showed a shepherd with his flock and a barn in the background. The rose is a traditional element of Bulgarian identity as Bulgaria cultivated roses, particularly in what became known as the Rose Valley, from the mid-15 ${ }^{\text {th }}$ Century on and exported rose oil from the mid$17^{\text {th }}$ Century on. The 18995 and 10 leva (Figures $1 \mathrm{a} \mathrm{\&} \mathrm{b)} \mathrm{repeated} \mathrm{the} \mathrm{designs} \mathrm{of}$ the 1890 issue. The 189950 leva repeated the design of the 1885 issues. The 1903 issues, known as the Orlov series after the name of their designer, Ivan Orlov, made a complete break with the past (Figures 2a \& b). Though more colorful than their predecessors the Orlovs had no pictorial elements other than the coat of arms, and several had a portrait orientation rather than landscape. The style of the bank became The Bulgarian National Bank.

The 1910 issue consisted only of a 5 leva banknote of Orlov design. This had the inscription Kingdom of Bulgaria around the coat of arms and was the only banknote on which this appeared. In 1908 the Young Turks had overthrown

\footnotetext{
${ }^{26}$ The issue of the optimal pattern of denominations is a complex one. See : Tschoegl (Adrian E.), " The Denominations of US Coins : A Case of Institutional Evolution n, Journal of Evolutionary Economics, (3), 2001.

${ }^{27}$ The lion rampant apparently originated in a book by Hristofor Zhefarovich, who in 1741 wrote the Stematografia, a discussion of the cultural history of the Serbs and the Bulgarians that included what some describe as imaginary heraldry. The work became popular in Bulgaria over the next century. One copy belonged to Vasil Droumev, a Bulgarian revolutionary who was one of the regents after Alexander Battenberg's abdication. See : Clarke (J.F.), "Serbia and the Bulgarian Revival (1762-1872) ", American Slavic and East European Review, (3-4), 1945.

${ }^{28}$ The information on the banknote issues from 1885 to 1997 comes from the Catalogue of Bulgarian Banknotes (Sophia : Bulgarian National Bank, 1999).

${ }^{29}$ Felix Kanitz was a Hungarian who traveled extensively in Bulgaria between 1860 and 1877 . During his travels he made many highly detailed sketches, drawings, and etchings.
} 
the Ottoman government. Taking advantage of this, Ferdinand of SaxeCobourg-Gotha, who had been elected Prince in 1887, proclaimed Bulgaria's independence from Turkey and himself $\mathrm{Tsar}^{30}$. With that proclamation, Bulgaria threw off the last vestiges of Ottoman suzerainty. Its next, but only its next, banknote reflected the change. Perhaps due to wartime stringency the issues of 1916 and 1917 were less colorful than the Orlov issues and also dispensed with pictorial elements beyond the coat of arms. The 19175 leva did include a crown but it was the exception.

In 1918, Tsar Ferdinand abdicated in favor of his son Boris. Ferdinand had led Bulgaria into two disastrous defeats - the Second Balkan War and the First World War - and had been fortunate in not being forced out after the first. From 1919 on Alexander Stamboliyski, leader of the Bulgarian Agrarian National Union, led a shaky coalition government and it was he who signed the Treaty of Neuilly in $1919^{31}$. As the proponent of an agrarian socialism, he launched a dramatic series of reforms before his overthrow and murder in 1923. Thereafter, the army supported now Tsar Boris III as he gradually established his personal control.

The banknotes of the time reflected some of this political turmoil, although the first few notes issued after the war had little or no symbolic content. The 10 leva note of 1919 was still simple and without pictorial elements. The 1 lev banknote of 1920 had on its obverse a picture of a sculpture of a seated woman dressed in a toga-like garment and turning to her right. The obverse had a picture of the BNB's original building, built in the late $19^{\text {th }}$ Century. The 2 leva banknote of 1920 had on its obverse almost the same picture as on the 1 lev, but here the woman was turning to her left (Figures за \& b). The reverse had a picture of the National Assembly Building in Sofia. These two banknotes were the only ones in the entire sequence of Bulgarian banknotes that had a (probably) allegorical female figure, though pure esthetics rather than symbolism may have been the reason behind the choice as I have been unable to find a meaning, if any, for these figures. Bolton points out that " the topos of a female in any kind of classical guise probably tended to prompt an attitude of reverence and vaguely allegorical associations in the $19^{\text {th }}$ century beholder ${ }^{32}$.

30 Ferdinand (1861-1948) was the son of Prince August de Saxe-Coburg-Gotha (of the cadet branch of the family) and Princess Clementine d'Orleans, daughter of King Louis Philippe of France. At the time of his election as monarch of Bulgaria he was a Second Lieutenant in the Austro-Hungarian army.

31 This Treaty provided for the reciprocal emigration of the ethnic minorities between Greece and Bulgaria and many credit it with being the first agreement in modern Europe to endorse mutual (compensated) ethnic cleansing. However, the earlier 1913 Convention of Adrianople, annexed to the Peace Treaty between Bulgaria and Turkey, provided for an exchange of ethnic Turks and Bulgarians in a 15 kilometer border strip.

${ }^{32}$ Bolten (Jaap), op. cit. p. 240. 
The 1922 series of banknotes was known as the Stamboliyski after the Prime Minister, or the Amerikanki issue because the printer was the American Bank Note Company, of New York. These notes returned to Bulgarian agricultural themes for their reverses. The contemporary artists Dimitar Gyoudzhenov and Nikola Kozhouharov drew scenes from Bulgarian country life. The 5 leva had a rural scene with two bee skeps (portable beehives often made of straw). The 10 leva featured a woman in national costume feeding poultry, with a house in the background. The 20 leva showed a woman reaper with a sheaf slung across the shoulder, with other reapers working in the background. The 50 leva had a shepherd playing a bagpipe while his flock rested around him (Figures $4 \mathrm{a} \& \mathrm{~b}$ ). The 100 leva had a ploughman with two oxen pulling the plough. The 500 leva departed from the entirely rural with its small cargo vessel at tied up at a quay in Varna, with wagons and bales in the foreground. Lastly, the 1000 leva banknote returned to the rural theme with a group of rose-pickers. This series introduced an international aspect with the legend Banque Nationale de Bulgarie on the reverse above the pictures. This element continued through all subsequent issues until 1950.

The 5000 leva banknote of 1924 introduced two changes. First, the obverse included a portrait in profile of Tsar Boris III in military uniform, as well as the seal of the BNB. The reverse included a portrait of Hristo Botev (1848-1876), and was the first banknote to feature a national hero. Botev was a Bulgarian poet who died at the head of a volunteer detachment fighting the Ottomans in the unsuccessful " April Uprising " that led to reprisals and ultimately to the Russo-Turkish War. He is known in Bulgaria for the poem Hadzhi Dimitur, which celebrates an earlier leader who died in battle against the Ottomans in 1868 , and contains the line : " He who falls while fighting to be free can never die ". Thus the note links the Tsar, the military, and a national hero.

The series of 1925 introduced a full-face portrait of Tsar Boris in military uniform on the obverse. The reverse introduced a mix of economic and national themes. The 20 leva banknote carried on the reverse a picture of the Pomorie salt works, which extract salt from the sea. The 50 leva had a group of reapers on the reverse. This is the central portion of Ivan Angelov's picture, Harvest (Figures $5 \mathrm{a} \& \mathrm{~b}$ ). The reverse of the 100 leva featured Anton Mitov's (1862-1930) 1903 picture, Peasants in a Marketplace in Sofia. The reverse of the 500 leva had a ploughman, a boy and two oxen, which reproduced the central portion of Yaroslav Veshin's (1860-1915) picture, Ploughman. The 1000 leva featured on its reverse Ivan Murkvichka's (1856-1938) picture, Allegory of Abundance. Murkvichka painted romantic genre paintings, often on the theme of Bulgarian village life after the liberation from the Ottomans. The 5 ooo leva banknote had as its reverse a picture of the St. Alexander Nevski Cathedral in Sofia, erected between 1892 and 1912 as a memorial to the 200000 Russian soldiers who died in the 1877-1878 Russo-Turkish war that brought 
about Bulgaria's independence. In 1926 the BNB lost its commercial banking functions. In 1928, an amendment to the 1926 law completed the conversion of the BNB to a fully-fledged central bank. Thus, the 1924 and 1925 banknote issues had the Tsar's portrait on the notes of a government-owned bank that still competed with private banks. The obverse of the 1929 series continued to feature Tsar Boris III in uniform. The 100 leva banknote featured on its reverse Murkvichka's painting Father Pyasutzi. Father Pyasutzi, also known as Pyasutzi Hilendarski (1722-1773), was a Bulgarian monk at Hilandar Monastery on Mt Athos. Using medieval texts, he prepared a history of the Bulgarian people that he started to circulate anonymously in $1762^{33}$. Pyasutzi's history marks the beginning of the National Revival (1762-1878), which resulted in the rapid expansion of Bulgarian schools and the achievement in 1870 of an independent Bulgarian Orthodox Exarchate.

The remaining four banknotes in the series switched emphasis by featuring landscapes on their reverses. The 200 leva banknote had a view of Veliko (Great) Turnovo, the old medieval capital. The 250 leva banknote had a view of the Iskur Gorge. The 500 leva had a view of the Seven Rila Lakes and the 1000 leva a view of the Yantra River near Veliko Turnovo.

The use of a 200 leva and 250 leva note is somewhat anomalous. Not only does the 250 leva break with the now European standard 1, 2, 5 sequence, the denominations of the two notes are too close together. When a denomination is less than twice the size of the preceding denomination one or the other is redundant ${ }^{34}$. Still, the two circulated in parallel from March 1941 to March 1947.

The 1938 issue represented something of a decline in imagery but an improvement in decoration and the use of color. All three notes had stylized art deco, floral or grape vine decorative borders and had a visual character quite unlike their immediate predecessors (or successors). The obverse of the three notes continued to feature the portrait of Tsar Boris III in uniform. For their reverses, the 500 leva banknote had a wheat sheaf and sickle (Figures $6 a \&$ b), the 1000 leva had no picture, and the 5000 leva had a picture of the BNB's new building, built between 1935 and 1939 .

The 1940500 leva banknote recycled the picture of the ship docked in Varna from the 1922500 leva and the 1 ooo leva recycled the ploughman from the 1922 1000 leva. The banknotes of the 1942 issue still carried Tsar Boris III in uniform. The 500 leva's reverse carried a portrait of a Bulgarian woman in traditional garb. The 1000 leva's reverse featured an engraving of the Rila Monastery. Bulgaria had adopted Christianity as the national religion in 864, and Ivan Rilski (876-946;

\footnotetext{
${ }^{33}$ Apparently it circulated in manuscript form for some 80 years before appearing in print, and then still anonymously, Clarke (J.F.), art.cit.
}

34 Tschoegl (Adrian), " The Denominations of US Coins... n (art.cit.). 
St. John of Rila) or his followers founded the monastery in 927 as a retreat for hermits. The monastery reputedly was built on the spot where the Saint died and since 1469 has housed his relics. When Bulgaria fell to the Ottoman Turks, the monks abandoned the monastery for a short time but it resumed functioning in the second half of the $15^{\text {th }}$ Century under a confirmation of its privileges in the form of an Ottoman decree or firman. Thereafter the monastery served as a major center for Bulgarian culture, education and literature, becoming one of the wellsprings of the Bulgarian Revival. The 5000 leva's reverse carried the more prosaic picture of the National Assembly building. Tsar Boris III died in August 1943, reportedly of natural causes. A three-man regency followed as his heir, Tsar Simeon II, was only six years old. All the banknotes of the 1943 issue, except the 20 leva, carried the new king's portrait on their obverse. The 20 leva banknote was extremely utilitarian with no pictorial elements. However, the 200 leva reused the view of Veliko Turnovo from the 1929250 leva banknote as its reverse. The 250 leva recycled the Ploughman from the 1925500 leva banknote, and the 500 leva recycled the bagpipe-playing shepherd from the 192250 leva banknote.

The 194420 leva banknote was as utilitarian as the 1943 had been. The banknotes of the 1945 issue were more elaborate and decorative, but still without pictorial elements.

Bulgaria, for irredentist reasons, allied itself with the Axis powers, but for philo-Russian reasons avoided declaring war on Russia or generally deploying troops outside the Balkans. Still, on 5 September 1944 the USSR declared war on Bulgaria and the Soviet Army invaded the country. Stalin appointed Georgi Dimitrov, a Bulgarian and a friend, to lead the Communist resistance 35 . A coup by the domestic Communist movement on 9 September 1944 enabled the Fatherland Front Government, headed by Kimon Georgiev, to come to power before the Red Army reached Sofia. Dimitrov became Prime Minister in 1946 and engineered a referendum that abolished the monarchy. The QueenMother, Tsar Simeon II and the Princess Maria-Louisa left Bulgaria for Egypt via Turkey.

The 194720 leva banknote no longer carried the royal coat of arms on its obverse or reverse. On its reverse it carried a drawing of the BNB building and across the center top a banner reading (in Bulgarian) Peoples' Republic of Bulgaria.

35 Dimitrov had co-founded the Bulgarian Communist Party in 1919 and led an uprising in 1923. Dimitrov served as secretary-general of the Comintern from 1934 until it was dissolved in 1943. In 1945, he returned to Bulgaria to head the Communist party there.. 


\section{THE COMMUNIST ERA}

The new regime took power and over a span of about four years eliminated almost all opposition. A key task for the new regime was to create a new "Socialist reality ". It proceeded to do so through, among other measures, the design of trademarks, logos and banknotes ${ }^{36}$. Themes would include progress, particularly in the form of industrialization, cooperative work, and Communist heroes.

The 1948 issue 200 leva banknote carried a new seal on the obverse : this had the Bulgarian lion, a five-pointed star and the date 9 IX 1944, commemorating Bulgaria's liberation from Fascism and the inception of the Socialist Revolution. The reverse had a picture of a stylized, heroic coal miner, stripped to the waist, using a jackhammer. The reverse of the 250 leva showed a train emerging from a tunnel with a truck in the background and an airplane overhead (Figures $7 \mathrm{a} \& \mathrm{~b}$ ). The 500 leva had a picture of two women picking tobacco on its reverse. None of the notes of this issue bore the Bulgarian People's Republic banner. In 1949, Dimitrov died in a sanitarium near Moscow. The government built a mausoleum in central Sofia, attended by an honor guard, to display his embalmed body. The 1950 issue 20 leva bank note simply reproduced the 194720 leva. In 1951, the Government made the BNB a government agency subordinated to the Council of Ministers and without ministerial status. The 1951 issue introduced a whole range of denominations. The 1 lev and 3 and 5 leva banknotes all had Communist coat of arms on the obverse, together with the Bulgarian People's Republic banner. On the reverse, all three carried a picture of two hands holding a crossed sickle and hammer. These notes carried wording to the effect that the Ministry of Finance had issued the notes. The higher denomination notes were more elaborate and did carry the BNB's name under the style, Bulgarian National Bank, giving up the definite article. All had a portrait of the late Georgi Dimitrov on the obverse, together with the seal and banner. The reverse of the 10 leva had a picture of a tractor pulling a reaper. The 25 leva had a picture of a youth brigade laying railroad track in front of a tunnel. The 50 leva carried as its picture a rose-picker holding two baskets of roses, one on her shoulder and one under her arm. The 100 leva featured a woman in national costume carrying two panniers of grapes. Both the rosepicker and the grape-picker were smiling directly at the viewer, a feature noticeably missing from prior and later pictures of working men and women. The 200 leva had on its reverse two women and a man picking tobacco.

36 Tzvetkova (Maria), "La propagande politique : l'exemple de la Bulgarie communiste à travers les marques et les logos n, Balkanologie, 2 (2), 1998. 
The pattern of denominations in this issue $(1,3,5,10,25,50,100,200)$ broke with all prior issues and general European practice. The 3 leva denomination was clearly an innovation, and the 25 leva somewhat of one. However the 3 leva and the 5 leva were too close to each other - technically the 5 leva was redundant but no country has a 1, 3,10 pattern - and the next issue returned to convention.

As with the 1, 3 and 5 leva banknotes of the 1951 issue, the 1, 2, and 5 leva banknotes of the 1962 issue had the coat of arms and the banner on the obverse. However, instead of the hammer and sickle, they carried pictures on their reverse. For the 1 lev this was a picture of the monument at Shipka Peak, which monument commemorated a desperate battle in the Russo-Turkish war when a contingent of Bulgarian volunteers and a Russian regiment together inflicted a critical defeat on the Ottoman Army for the control of the Shipka Pass. Although the notes of the Communist era generally eschewed references to Bulgaria's pre-Communist past, at least other than references to the Bulgarians as a people, this note established a parallel between Russian assistance in 1877-1878 and 1944. The 2 leva had a woman picking grapes. The 5 leva had a picture of Zlatni Pyasutzi (Golden Sands), Bulgaria's premier resort, which the Communist regime had established. These banknotes returned to BNB emanations carrying the BNB's name rather than being Ministry of Finance notes. The 10 and 20 leva banknotes continued Dimitrov's portrait on the obverse. The 10 leva featured the Devnya Chemical Works on its reverse, and the 20 leva featured the Maritza Iztok thermoelectric power plant. The government had recently constructed the plant to use local lignite. The 1974 issue (Figures $8 \mathrm{a} \& \mathrm{~b}$ ) replicated the 1962 issue, though with a small change. The new coat of arms featured the years 681 and 1944 in place of the earlier 9 IX 1944. This united the Communist regime with the origins of the Bulgarian people. The Bulgarians date the origins of their country to 681 when Asparuh (also Isperih), a Proto-Bulgarian khan, established the First Bulgarian State (681-1018). The 1974 issue, therefore, anticipated Bulgaria's celebration in 1981 of its 1300-year anniversary.

The regime of Todor Zhivkov, Bulgaria's totalitarian ruler, collapsed on November 10, 1989, the day after the fall of the Berlin Wall. However, unlike the overthrows of Communist governments elsewhere in Eastern Europe, Bulgaria's " revolution " was an internal coup within the Communist Party not a popular revolt. One issue was Zhivkov's failure to implement perestroika. Zhivkov, who had headed one of the most hard-line communist regimes in Eastern Europe for 35 years, was unwilling to change. A second important issue was Zhivkov's decision in early 1989 to permit the ethnic Turkish minority to leave Bulgaria, which led to a mass exodus that drew unfavorable international attention. From Dimitrov on, the Bulgarian Communist regime encouraged the assimilation of the Turkish minority in eastern and southern Bulgaria, 
after initially forcing some emigration in the 1950s. Attempts to speed-up assimilation in 1984-1985 had led to demonstrations and riots 37 . (In the years after the exodus about half the 300000 emigrants returned, disappointed at living conditions in Turkey ; the Turkish minority now accounts for about $9 \%$ of Bulgaria's population and is the largest single minority.) Foreign Minister Petar Mladenov, who had mobilized the anti-Zhivkov sentiment within the Communist Party, replaced him. Mladenov became Chairman of the Council of State and then briefly, in 1990, President of the Republic of Bulgaria. In mid1990 the Government also removed Georgi Dimitrov's body from its mausoleum and cremated it. In 1999 the Government finally demolished the building.

The 199050 leva issue represented a transition. It still featured the People's Republic banner and the Communist coat of arms on the obverse. However, in a return to pre-Communist themes, the banknote's reverse featured the Tzarevetz castle in Veliko Turnovo. Tzarevetz included the Tsars' and the Patriarchs' palaces from the Second Bulgarian Kingdom (1181-1395/6), as well as a number of other churches and buildings.

\section{THE POST-COMMUNIST ERA}

Bulgaria has been a parliamentary democracy since 1990 with several parliamentary and presidential elections since the fall of the Communist dictatorship. In 1997, after a period of instability and a hyperinflation in 19961997, Bulgaria entered a period of political and monetary stability. Ivan Kostov, of the United Democratic Forces, became Prime Minister in 1997, having defeated the Bulgarian Socialist Party, the successor to the Communist Party. In June 2001, Bulgaria's former Tsar Simeon II defeated Kostov in elections ${ }^{38}$. As far as the supply of money is concerned, and its embodiment in banknotes, the postCommunist era began with banking system reforms in 1989-1990. The Law on the Bulgarian National Bank (1991) returned the BNB to the role of Central

37 Dimitrov (Vesselin), " In Search of a Homogeneous Nation : The Assimilation of Bulgaria's Turkish Minority, 1984-1985 ", Journal on Ethnopolitics and Minority Issues in Europe (www.ecmi.de/jemie/). Erhard (Franz), "The Exodus of Turks from Bulgaria, 1989 ", Asian and African Studies, (1), 1991.

$3^{8}$ Simeon Borisov Sakskoburgotski is a descendent of the Hungarian branch of the House of SaxonyCoburg-Gotha, and therefore related to Prince Albert, the husband of Queen Victoria. His mother Giovanna was the daughter of King Vittorio Emanuelo III of Italy. His wife Margarita is descended from the House of Savoy. Simeon attended high school at Valley Forge Military Academy in Wayne, Pennsylvania. The former Tsar, who had never renounced the throne, then spent his adult life as a businessman in Spain, though doing what is not entirely clear. On his return the Kostov government permitted him to reclaim his confiscated property. This made him one of the richest men in Bulgaria. 
Bank with monetary and regulatory powers and responsible to Parliament. The BNB issued its first new banknotes in 1991. As D. Blaazer points out with respect to British banknotes, countries can use money to " invent " tradition 39 . In E. Hobsbawm's words, " where possible, they normally attempt to establish continuity with a suitable past. (...) The peculiarity of "invented" traditions is that the continuity with [the past] is largely factitious. In short, they are responses to novel situations which take the form of references to old situations " 4 .

Since the fall of the Communist regime, ideology in Bulgaria has followed two themes. One theme has stressed a pan-Slavic, Orthodox, nationalist orientation. The other has sought to link Bulgaria with the European Union and NATO. The pan-Slavic, Orthodox, nationalist orientation dominates the banknotes. All the notes are modern in design and generally feature a Bulgarian national figure - human or architectural - on the obverse, with related elements appearing in the background and on the reverse.

The Bulgarian post-Communist banknotes share many characteristics with those of other formerly Communist countries ${ }^{41}$. They also share many characteristics with the postage stamps of the newly independent countries that emerged from the breakup of the Soviet Union, Yugoslavia and Czechoslovakia that S.D. Brunn examines ${ }^{42}$. First, the notes re-establish a connection with past cultural and political identities. Second, portraits of key historic personalities, particularly those of the $19^{\text {th }}$ Century dominate the imagery. The portraits serve two purposes. The human ability to recognize faces at a glance means that the various portraits provide redundant signals of the banknotes' denominations. In addition, they honor national heroes and cultural figures and so reinforce the connection between money and the nationstate. The portraits are predominantly of males, though the presence of the occasional non-allegorical or non-generic female actually represents a (small) step forward. Drawing on the $19^{\text {th }}$ Century for heroes reflects several issues. First, much of the $20^{\text {th }}$ Century and its figures remain problematical. Second, the $19^{\text {th }}$ Century was the period of the rise of nationalism and in Bulgaria in particular, the flowering of the Bulgarian Revival. The last feature that the

${ }^{39}$ Blaazer (David), " Reading the Notes : thoughts on the meanings of British paper money ", Humanities Research, (1), 1999.

$4^{\circ}$ Hobsbawm (Eric), " Introduction : Inventing Traditions », in Hobsbawm (Eric), Ranger (Terence), eds., The Invention of Tradition, London : Canto, 1992, pp. 1-2.

${ }^{4}$ Unwin (Tim), Hewitt (Virginia), " Banknotes and national identity in central and eastern Europe ", Political Geography, 2001. See also their database on the banknotes of the post-Communist states : http://www.gg.rhul.ac.uk/tim-banknotes.

$4^{2}$ Brunn (Stanley D.), " Stamps as iconography : Celebrating the independence of new European and Central Asian states ", GeoJournal, 2000. 
post-Communist banknotes share is a frequent use of Christian imagery in the form of persons and churches. This may represent both an explicit about face from the policies of the predecessor regimes as well as recognition of the role that Christianity played in shaping the national identity in the past 43 . However, the Christianity that the Bulgarian notes celebrate is Orthodox Christianity, thereby defining the Bulgarian nation as neither Western Christian nor Islamic. At some point Bulgaria's banknotes may acknowledge the Moslem minority. So far they do not.

One theme that transcends a number of the post-Communist Bulgarian notes is the depiction of national architecture. Some of the architectural elements are historic buildings and some are monuments. Although architecture is immobile, stamps, coins and banknotes are mobile, even across borders 44 . They thus carry the architecture with them throughout the country and beyond, exposing the user to these lieux de mémoire or seats of memory. The notes of pre-1990 Bulgaria showed a number of buildings but almost none of any historical importance, and the only monument was that commemorating the battle at Shipka Pass, which had philo-Russian connotations. The postCommunist notes show more.

The obverse of the 20 leva banknote depicted the Duchess Desislava (Figures $9 \mathrm{a} \& \mathrm{~b}$ ). In the $11^{\text {th }}$ Century, she and her husband, the Duke Kaloyan, donated the funds used for the construction of the Boyana Church in what is now an outlying suburb of Sofia. An unknown artist of the $13^{\text {th }}$ Century painted numerous frescoes in the church, two of which represent the donors. The banknote's reverse had a drawing of the Boyana Church itself. This banknote is the first in the whole history of Bulgarian banknotes to have featured a named woman. Though women have appeared frequently it has always been in generic roles 45 .

The 1991100 leva banknote carried a portrait of Zahariy Zograf (1810-1853) on its obverse. Zograf painted frescoes inspired by medieval Bulgarian art and was one of the first painters to make the transition from religious to secular painting. The banknote's reverse depicted the Circle of Life, one of his works. It consists of four circles : in the center circle is Fate ; the next link the months, the seasons, and the stages of human life. Thus the segment that contains December, January, and February also contains winter and old age and death.

\footnotetext{
43 Unwin (Tim), Hewitt (Virginia), art.cit.

44 Schwarzenbach (Alexis), op. cit., p. 28.
}

45 As Natmeßnig (C.), art.cit., points out, the portrayal of named women on high-value notes is a rare occurrence everywhere. Unwin and Hewitt (Unwin (Tim), Hewitt (Virginia), art.cit.) report that the female images on banknotes from post-Communist East and Central Europe tend to be of women involved in the Arts, ideal representations, or on low denominations. Of course, lower denomination notes circulate more widely than higher denomination notes. 
The 199250 leva banknote had on its obverse a portrait of Hristo G. Danov (1828-1911), the "father of Bulgarian printing " who established the first Bulgarian publishing house in Plovdiv in 1887 . The reverse depicted his printing press, the first in Bulgaria. The third of the 1992 issue of banknotes was the 200 leva. On its obverse it carried a portrait of Ivan Vazov (1850-1921). His novel Under the Yoke (1894; Eng. trans., 1894) described life in Bulgaria towards the end of the period of Ottoman rule. In 1894, Vazov was elected to the National Assembly and from 1897 to 1899 served as Minister of Education. In addition to his novels, Vazov wrote poetry and plays. The note's reverse showed a lyre and wreath, which represent a literary prize that he received in 1895 .

In 1993, the BNB issued one banknote, the 500 leva. It depicted the composer Dobri Hristov (1875-1941) who had written liturgical music, four orchestral works and over 500 songs. The reverse depicted three seagulls skimming waves and the Opera House in Varna where he had organized the first musical festival in 1926.

In 1994, the BNB issued two banknotes, the 1000 and 2000 leva. The obverse of the 1 ooo leva banknote depicted Vasil Levski (1837-1873), " the Apostle of Freedom " and a hero of the Bulgarian struggle against the Ottoman Empire. "Levski " means " like a lion " in old Bulgarian and he apparently received the sobriquet while serving in Georgi Rakovski's (1821-1867) Bulgarian legion in Serbia in 1862. Later Levski became a revolutionary organizer. Betrayed to the Ottomans, he was tried and hanged in Sofia in 1873. The obverse also carries elements from Georgi Danchov's lithograph, Liberated Bulgaria, in the form of a woman holding a flag, with a lion beside her, as well as Levski's most famous quote : "If I prevail, all the people will prevail ; if I lose, I will lose myself only ". The reverse shows the monument built on the site of the gallows where he was hanged ; it also depicts the Bible, the cross, the knife, and the pistol that Levski and his compatriots used as a symbol of their secret organization. The script is the oath that Levski and his fellow rebels took upon entering the organization.

The portrait on the obverse of the 19942 ooo leva banknote was that of the Bulgarian architect Nikola Fichev (1800-1881) and drew on Boris Denev's picture of Nikola Fichev in profile. The background featured some of his projects including the belfry of the St. Konstantin and Helena church in Veliko Turnovo. The reverse depicted his Holy Trinity Church in Svishtov, the layout of the church, and the bridge over the Yantra River near Byala. It also included a sample of his handwriting.

In 1996 the BNB issued a 5000 leva banknote with a portrait of Zahari Stoyanov (1851-1889) on the obverse. Stoyanov too was a revolutionary. Both the banknote's obverse and the reverse featured facsimiles from his Sketches on the Bulgarian Upheavals, in which he described his experiences in rebel- 
lions against the Ottoman Empire. The reverse also depicted portions of the monument in Plovdiv dedicated to Eastern Roumelia's union with Bulgaria.

In December 1996 the BNB issued a 10000 leva banknote that it had intended as the last banknote of the series that it had begun in 1991. The obverse had a portrait of Vladimir Dimitrov-Maystora (Dimitrov the Master ; 1882-1960), who specialized in painting Bulgarian rural and landscape themes. The background element was the National Academy of Arts, which celebrated its 10oth anniversary in 1996. The reverse carried the print interpretation of his painting Bulgarian Madonna against a background of plant life motifs, fragments from his sketches, and a facsimile of a manuscript with his signature.

Early in 1997 the BNB issued a second 10 ooo leva. The obverse featured Dr. Petur Beron (1799-1871) who in 1824 published his Textbook with Miscellaneous Teachings with information on grammar, natural sciences, mathematics, anatomy, and history, as well as an introduction to the then novel Bell-Lancaster method of teaching. This, the first textbook in Bulgarian, was popularly known as the Fish Textbook for the picture of a whale on its front page, and represented a first step in the creation of a modern system of education in Bulgaria. The obverse of the banknote depicts the title page of Dr. Beron's textbook, as well as drawings taken from it. The reverse features other drawings from the textbook, including a telescope and a sextant, along with a depiction of the phases of the Moon.

With the pace of inflation accelerating, in May 1997, the BNB issued a 50 ooo leva banknote. The obverse features the statues of the brothers St. Cyril and St. Methodius that stand in front of the National Library in Sofia. The saints created the Cyrillic and Glagolitic alphabets, first adopted in Bulgaria in the $9^{\text {th }}$ Century, and are patron saints of literacy, literature, and learning. The background to the statues comprises the Cyrillic and Glagolitic alphabets and excerpts from a manuscript by Chernorizets Hrabur (10 ${ }^{\text {th }}$ Century AD). The banknote's reverse depicts architectural elements from the ancient Bulgarian capitals of Pliska and Preslav, as well as a facsimile of text from Pyasutzi Hilendarski's history.

In July of 1999, the Government announced a currency reform in which one new lev would equal 1000 old leva. As a result it also introduced a new set of banknotes to replace the issues of 1992 through 1999. The new issue retained the artistic style of the issues it replaced, but with changed pictorial elements 46

The obverse of the 1 lev banknote features an icon dating to 1789 of St. John of Rila (876-946) from the Church of the Assumption of Our Lady in the 
Hermitage near the Rila Monastery. The reverse depicts the principal church in the Rila Monastery as well as the cloister's open-air walkways. At the time that the BNB issued the banknote the Orthodox Church protested linking the Saint with something as profane as money.

The obverse of the 2 leva banknote carries a portrait of Pyasutzi Hilendarski, together with images of the Zografou Monastery and the Monastery's seal, and Father Pyasutzi's cell. The reverse features a facsimile of an excerpt from the Istorya-Slavyano-bulgarska overprinted with the seal from Tsar Kaloyan's ring together with the seals of the Bulgarian rulers Mihail Shishman and Svetoslav Terter, and Tsar Ivan Asen II. It also shows Hristofor Zhefarovich's lion rampant with the names of Bulgarian rulers from the First and Second Empires overprinted in microscopic lettering. At the bottom right is Bulgaria's Coat of Arms with three lions couchant dexter regardant (resting facing right looking at the viewer), as it appears in the Gruenberg Heraldic Compendium (1483).

The obverse of the 5 leva banknote is a portrait of Ivan Milev (1897-1927), one of the first exponents of art nouveau in Bulgaria, and a romantic with a strong feeling for Bulgarian legends. The background shows details of his painting Art and the Crown of Thorns, together with decorative motifs from other works, excerpts from his letters, and a monogram from an advertisement for his first exhibition, which he held in Sofia in 1925. The reverse features elements from his paintings A Woman Harvesting, The Bulgarian Madonna, and Wedding of the Dragon.

The 10 leva banknote essentially repeats the design of the 199710 ooo leva that featured Dr. Petur Beron (Figures 10a \& b).

The obverse of the 20 leva banknote features a portrait of Stefan Stambolov (1854-1895), the controversial post-Liberation Bulgarian statesman who was assassinated a year after having had to resign as Prime Minister. The central part carries a facsimile of the cover of his anthology Songs and Poems and his poem To My Comrades. Below appears the Seal of the Unity Committee in Turnovo, which he co-founded. The reverse depicts the National Assembly's building together with decorative elements from Sofia's Eagles' and Lions' Bridges. The Eagles' Bridge was built in 1891 on the site where the first governor of Sofia welcomed Bulgarians released from Ottoman prisons in Asia Minor in 1878. The note also features a manuscript of Stambolov's.

The obverse of the 50 leva banknote features a portrait of Pencho Slaveykov (1866-1912), a poet who introduced European literature into Bulgaria ; his Song of Blood is an epic about the struggle against the Ottomans. The background includes detail of the National Theatre and the National Library. The banknote's reverse carries illustrations from Slaveykov's books of poetry. It also features a portrait of Mara Belcheva (1868-1937), his great love and a fellow poet. She is only the second named woman to appear on a Bulgarian banknote. 
In 2003, the BNB introduced a new 100 leva banknote, which celebrates Aleko Konstantinov (1863-1897), writer, humorist, democrat, and creator of the organized hiking movement. In 1895 he led a party of three hundred enthusiasts to the highest point on Mt. Vitosha, a climb that marked the beginning of trekking in Bulgaria. In 2003, a bust of Konstantinov was unveiled at the library of the University of Chicago, the first bust in the US honoring a Bulgarian. Konstantinov had visited the 1893 World's Fair in Chicago and had written an account of his travels there via New York and Niagara Falls. On its obverse, the note features his image, a facsimile of the title page of the first edition of his book, A Journey to Chicago and Back, and various motifs from the Bulgarian trekking movement. The note's reverse features other items from his life and works.

\section{CONCLUSION}

The BNB's catalogue of its banknote issue has the following paragraph : " The nominal value, design and style of the Bulgarian banknotes reflect different stages in the development of the state, changes in its organization, economy, agriculture, culture, etc. They are part of the symbols of the system of state and preserve in a unique manner the historical and cultural memory of the Bulgarian people " 47 . All this is true, but incomplete. Banknotes, like other advertisements, present a selective picture, literally and figuratively. The government excludes references to aspects of the country and its history that are controversial and includes as pictorial and symbolic elements those aspects that it is proud of or that convey the message that it wishes to convey.

Two themes transcend the 100-plus years of Bulgarian banknotes, one by its absence and one by its persistence. First, there is no reference to the country's minorities, especially the Turkish minority. The only references to the Ottoman period are to the struggle to maintain a Bulgarian identity and culture and to the struggle for independence. Bulgaria is clearly defining its nationalism in terms of ethnicity (jus sanguinis) not territory (jus solis). Second, this is the reverse to an obverse of a persistent theme of Bulgarian nationhood. The primary symbol of this nationhood is the Bulgarian lion, though subsidiary themes such as roses too persist. The lion is present not just in the name of the currency, which survived numerous redenominations, but as a pictorial element, even if only as a watermark. Still, as one would expect, as regimes changed, so did the banknotes. The new country featured the sources of its

47 Catalogue of Bulgarian Banknotes (op. cit.), p. 6. 
prosperity. An agrarian reformer featured an idealized peasant life. A Tsar featured his regal bearing and the beauty of his Kingdom. A Communist regime focused on workers, peasants, and the industrial progress that it had brought. Lastly, a new Republic, breaking with the Communist past and anxious to take its place in Europe, invented tradition by focusing on its cultural history to create a national cultural identity.

As an initial attempt to make a point with material spanning over a century and many regime changes, this paper has necessarily favored breadth over depth. There is thus great room for further research, both diachronic and synchronic. Along the diachronic dimension, one useful direction would be detailed, archive-based analyses (both Central Bank and newspaper) of particular design decisions at points of change in regime. Another would be studies of the changing treatment of women or ethnic minorities as a function of regime change. Along the synchronic dimension, there are possibilities for studies of the differences in design decisions between regimes. For instance, do monarchies where the monarch is Head of State but not Head of Government and appears on the notes, have banknotes whose design is apolitical. That is, for these monarchies does a politically neutral design signal a politically neutral institution?

These and many similar questions suggest that coins, banknotes, stamps and other state emanations remain a potentially rich source of data. However, the ability of researchers to explore these questions will require the development of more country studies and cross-national annotated databases. 
Adrian E. Tschoegl - Change the regime - change the money: Bulgarian banknotes, 1885-2003 27

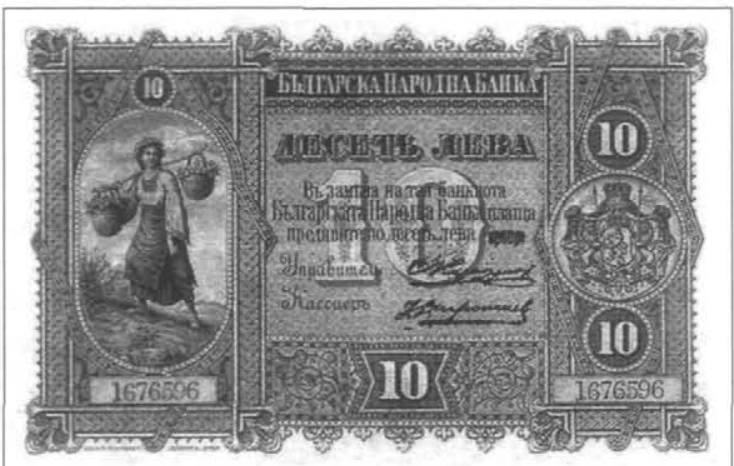

Figure 1a

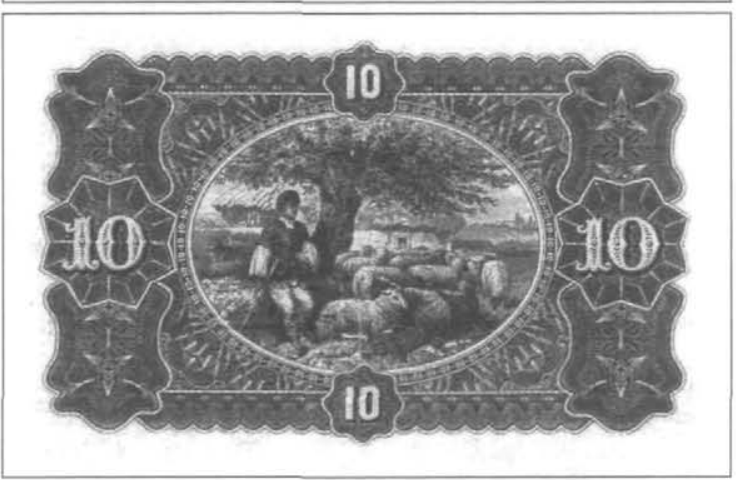

Figure 1b

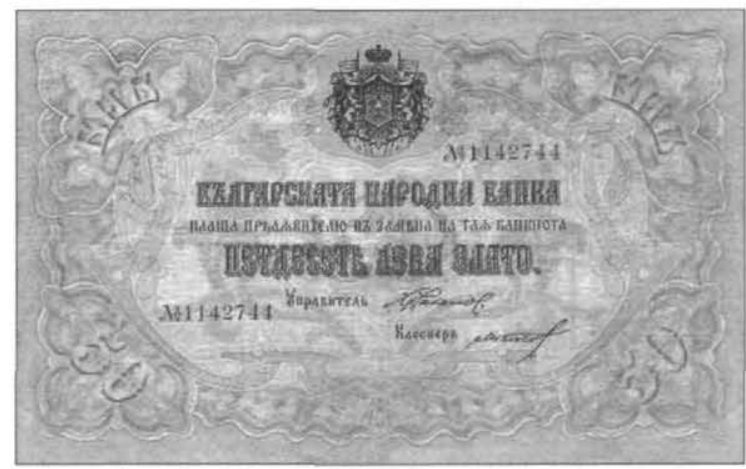

Figure 2a

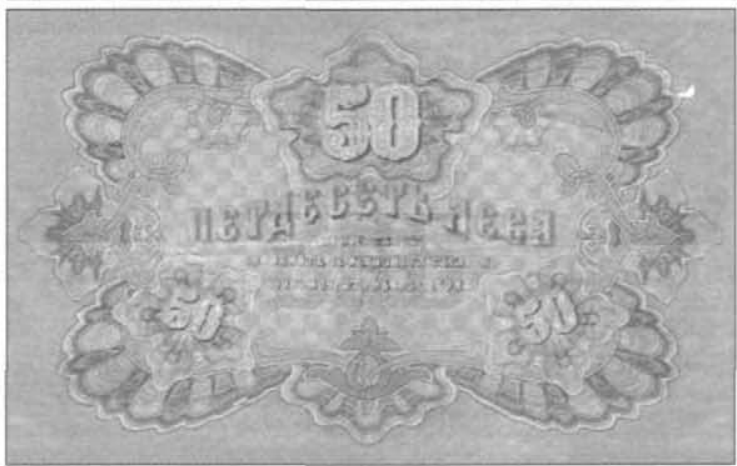

Figure 2b 


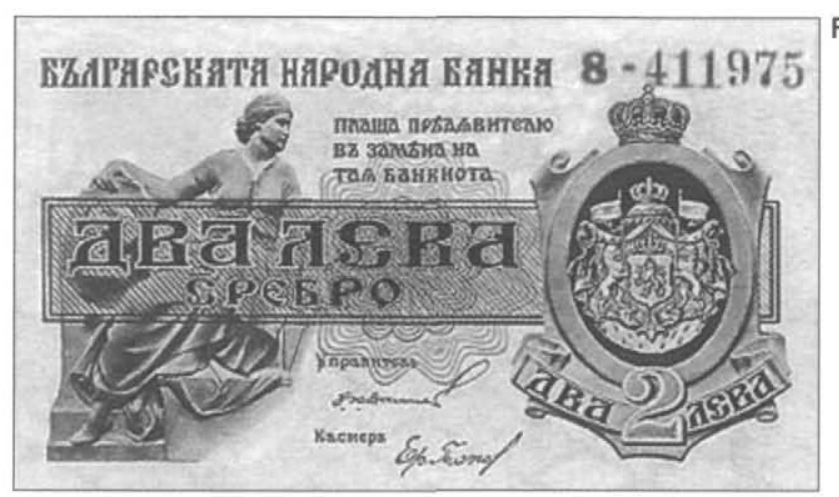

Figure 3a
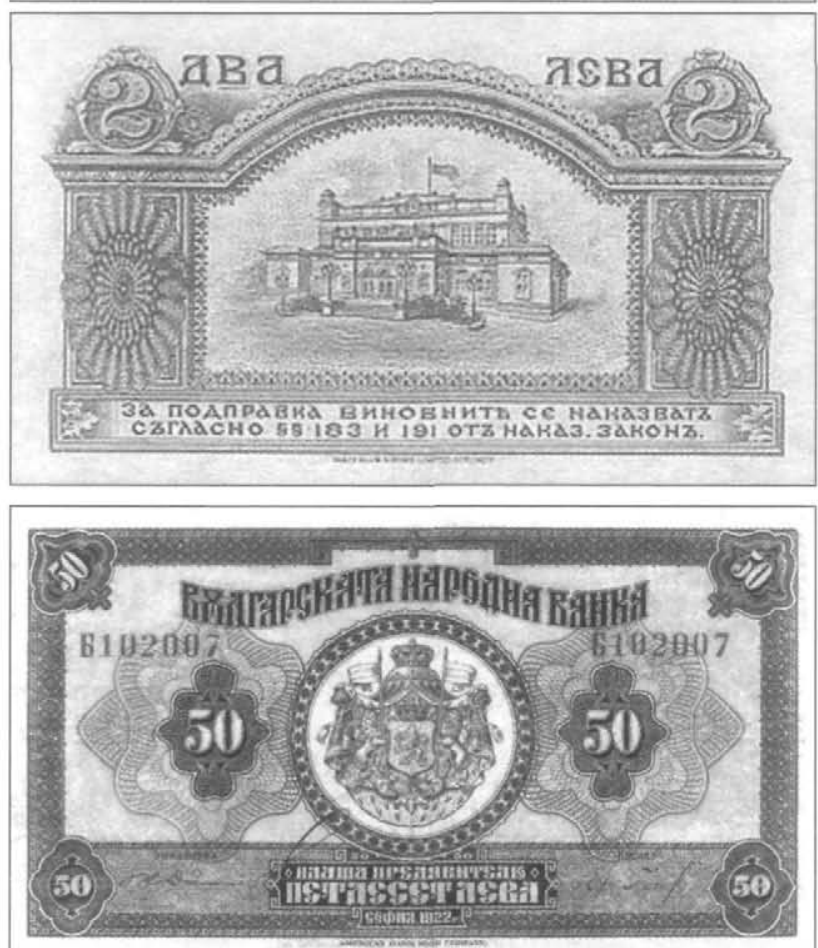

Figure 3b

Figure 4a

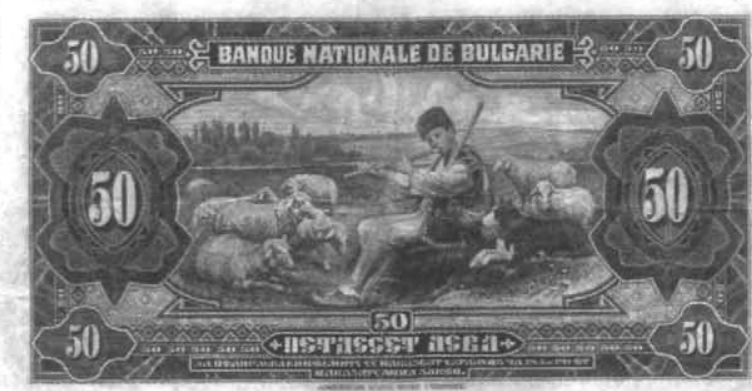

Figure 4b 


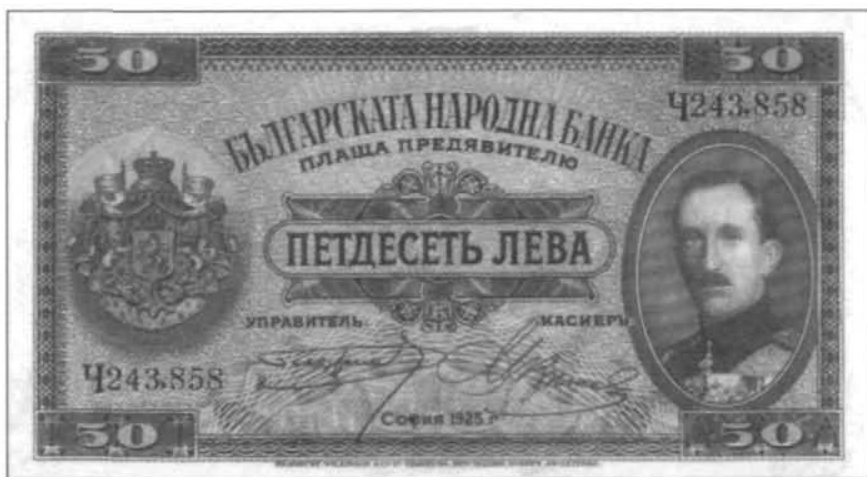

Figure 5 a

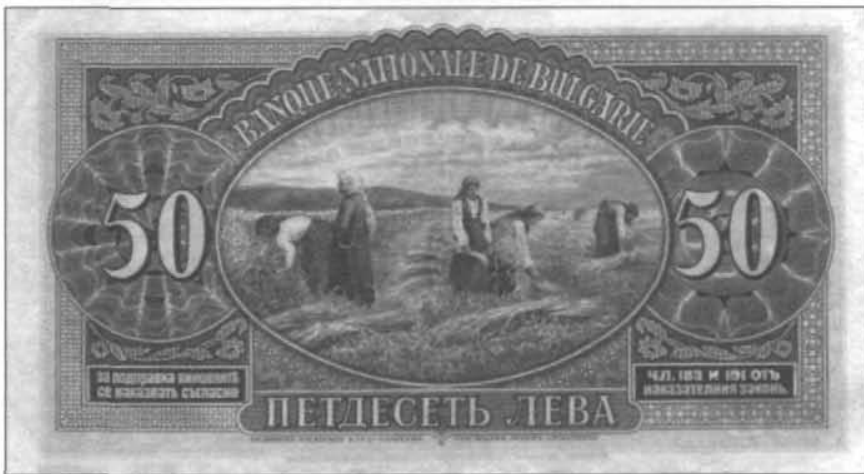

Figure 5b

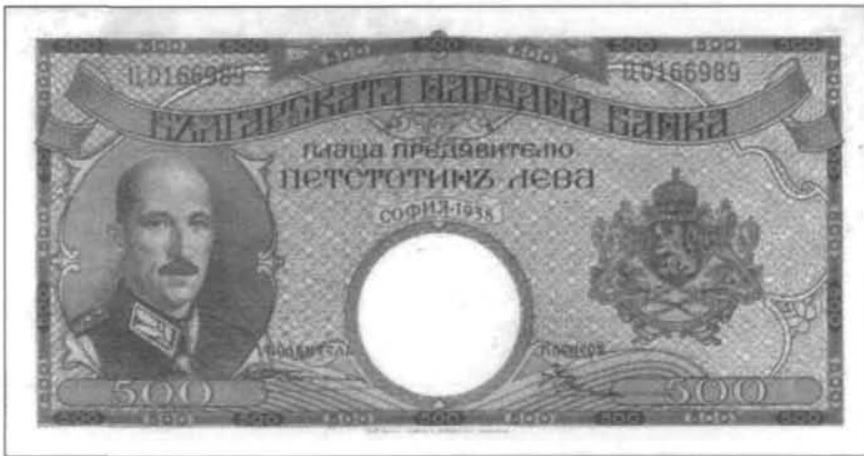

Figure 6a

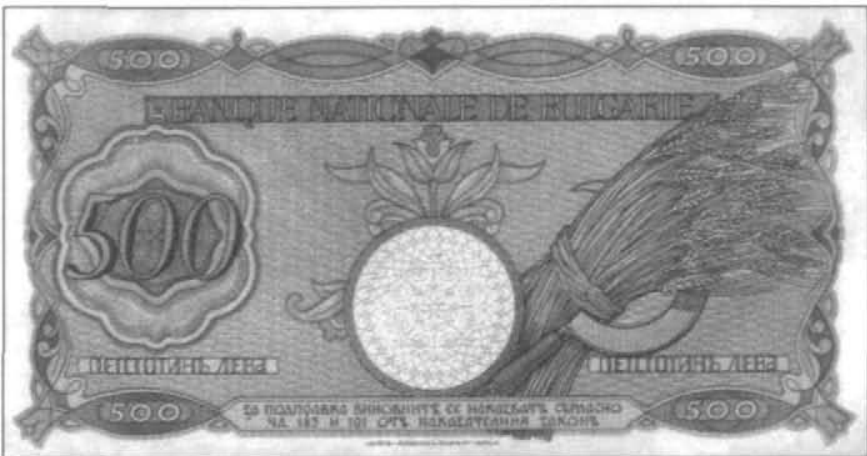

Figure 6b 


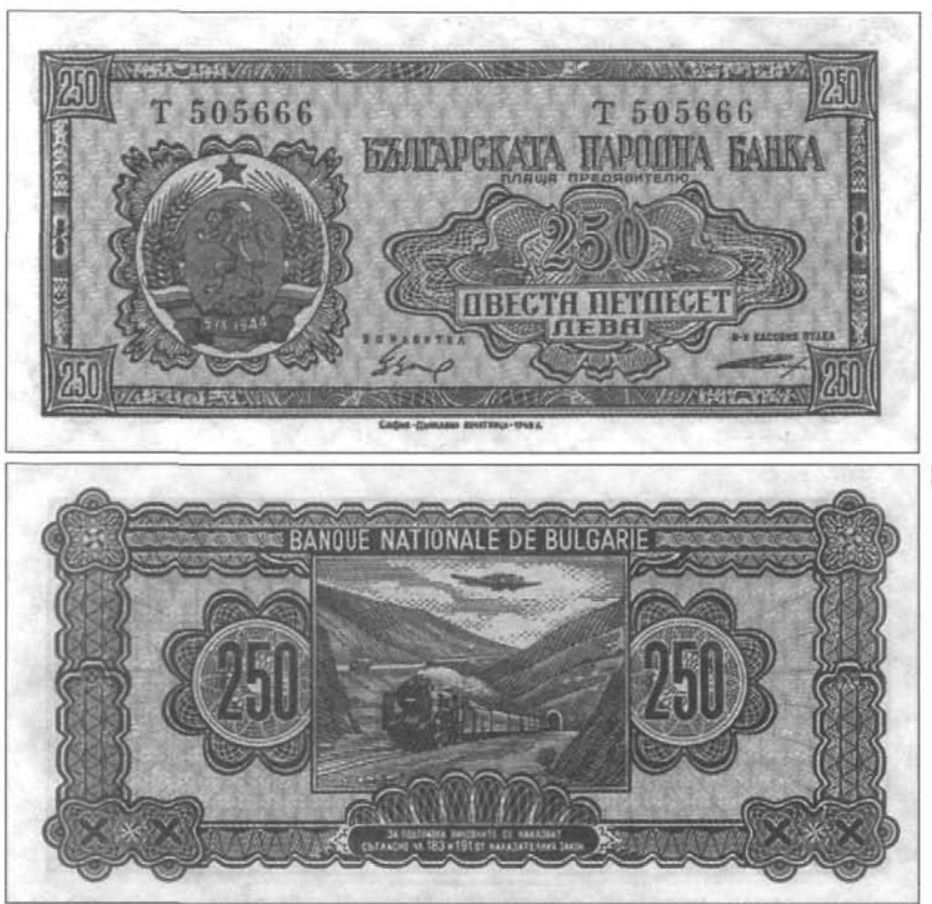

Figure 7 a

Figure $\mathbf{7 b}$

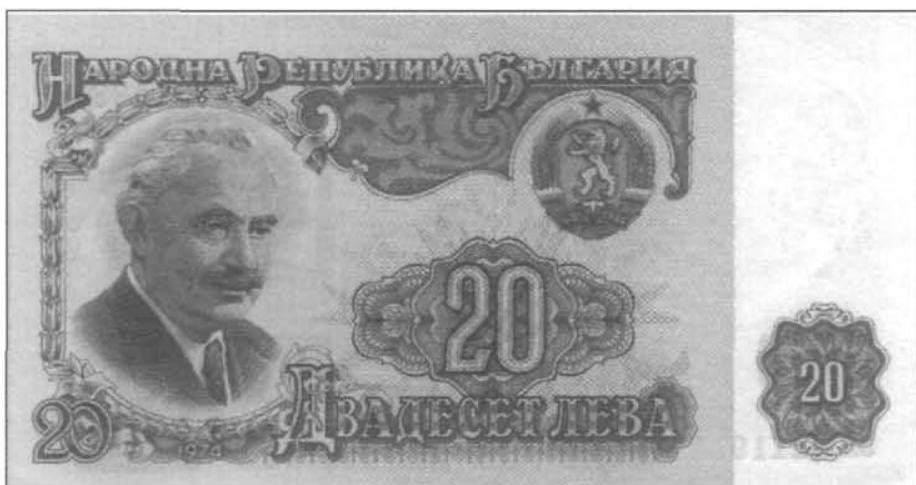

Figure 8a

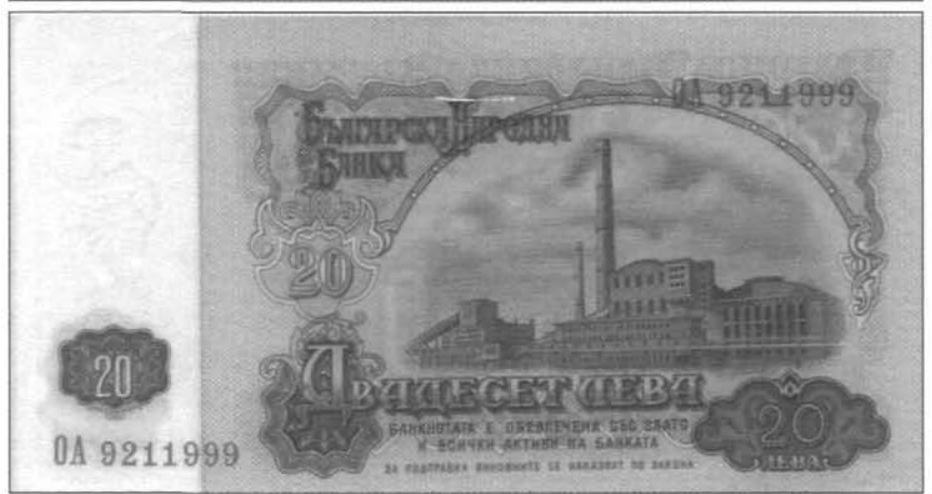

Figure 8b 


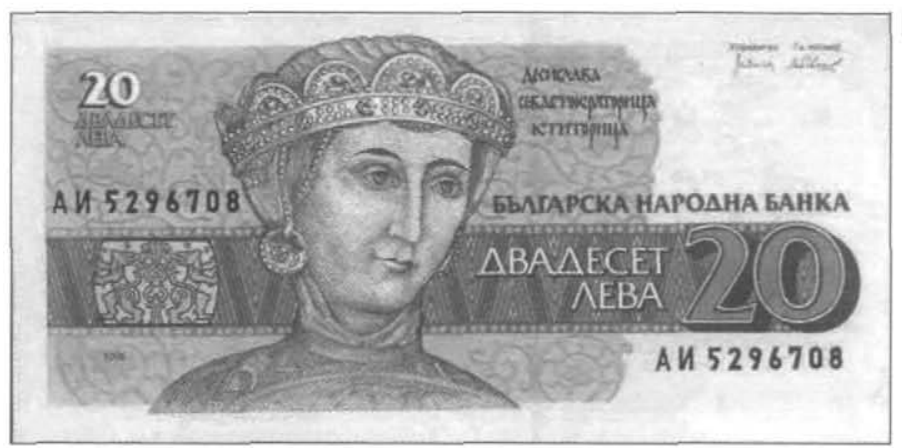

Figure 9a

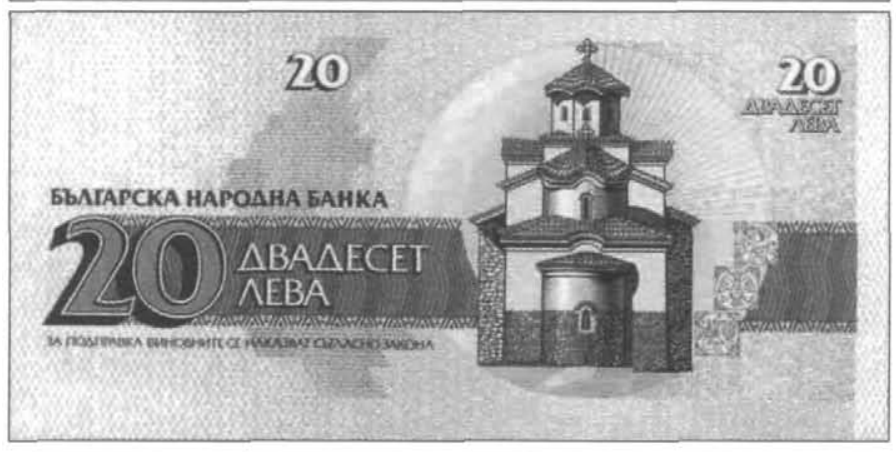

Figure 9B

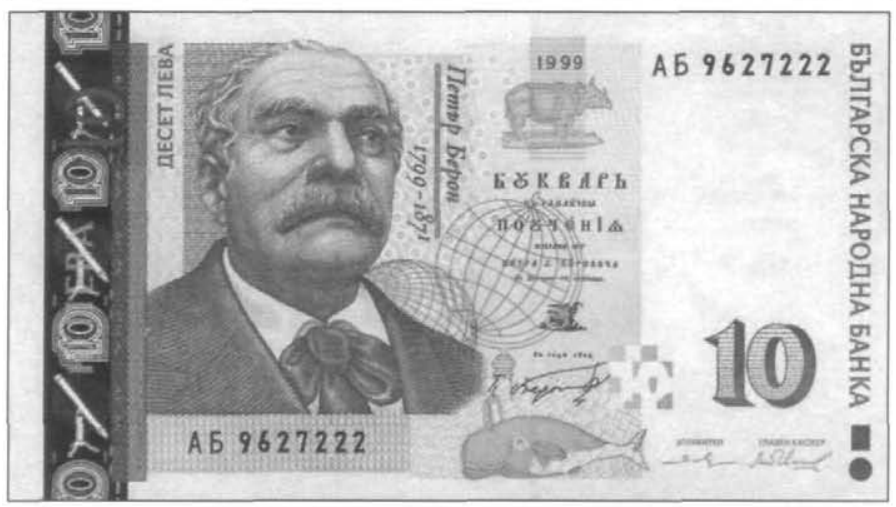

Figure 10a

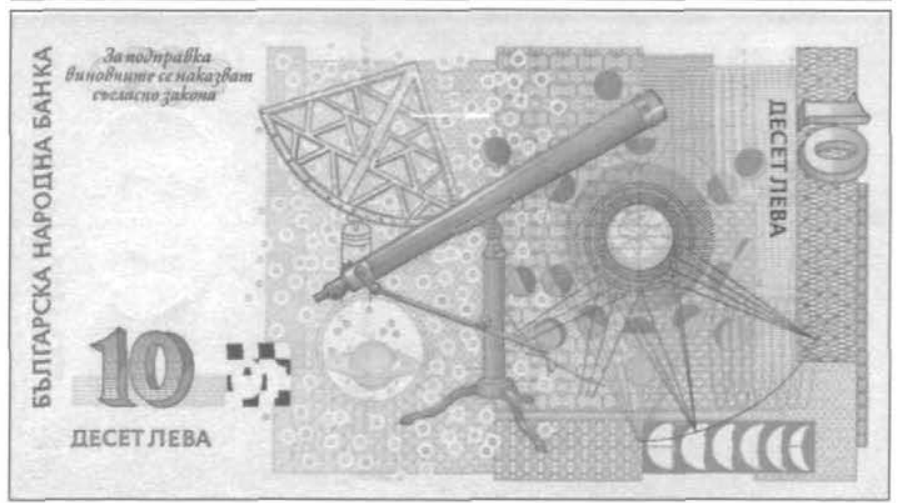

Figure 10b 